\title{
SEL BAHAN BAKAR BERBASIS MIKROBA-TANAMAN (P-MFC) SEBAGAI SUMBER ENERGI LISTRIK; PRINSIP KERJA, VARIASI DESAIN, POTENSI DAN TANTANGAN
}

\author{
PLANT MICROBIAL FUEL CELL (P-MFC) AS ELECTRICITY SOURCE; \\ WORKING PRINCIPLE, DESIGN VARIATIONS, POTENTIAL AND \\ CHALLENGE
}

\author{
Dwi Cahyani' ${ }^{1}$, Agus Haryanto ${ }^{2}$, David SS Marpaung ${ }^{1}$, Raizummi Fil'aini1 \\ ${ }^{1}$ Program Studi Teknik Biosistem, Institut Teknologi Sumatera \\ ${ }^{2}$ Jurusan Teknik Pertanian, Universitas Lampung \\ 『Komunikasi penulis, email: dwi.cahyani@tbs.itera.ac.id \\ DOI:http://dx.doi.org/10.23960/jtep-lv9i2.112-121
}

Naskah ini diterima pada 2 Juni 2020; revisi pada 12 Juni 2020;

disetujui untuk dipublikasikan pada 15 Juni 2020

\begin{abstract}
Plant Microbial Fuel Cell or known as P-MFC, is an emerging technology to produce electricity. P-MFC is projected as a possible solution in developing an alternative source of electricity that is highly available and sustainable. PMFC is not releasing pollution during the running time because the only side product of this technology is water $\left(\mathrm{H}_{2} \mathrm{O}\right)$. The national potential of P-MFC was calculated as much as 0,07 TW per year, which equal to 0,026\% of national electricity production. The P-MFC designs for research purposes has already been variously created compare to the initial introduction. Besides, the plant type occupied has been diverse as well. This article reviews four main parts of P-MFC technology. Firstly, an explanation of fundamentals processes in P-MFC and its plant. Secondly, about the P-MFC design variations and its power output. Thirdly, about P-MFC power potential in Indonesia and lastly, about the challenge of P-MFC application.
\end{abstract}

Keywords: bioenergy, electricity, fuel cell,P-MFC

\section{ABSTRAK}

Sel Bahan Bakar Berbasis Mikroba-Tanaman atau lebih dikenal dengan Plant-Microbial Fuel Cell (P-MFC) adalah teknologi baru terbarukan untuk memproduksi listik. P-MFC menjadi solusi potensial dalam pengembangan energi listrik alternatif yang mudah didapatkan dan ramah lingkungan. P-MFC tidak menimbulkan polusi saat digunakan karena satu-satunya hasil samping yang ditimbulkan adalah air $\left(\mathrm{H}_{2} \mathrm{O}\right)$. Potensi P-MFC di Indonesia menurut hasil pengkajian adalah sebesar 0,07 TW per tahun. Nilai yang cukup besar, setara dengan 0,026 \% dari kapasitas pembangkit listrik nasional. Listrik yang dihasilkan oleh teknologi ini dapat diperoleh langsung (insitu) di lokasi peletakkan reaktor P-MFC. Desain P-MFC sudah sangat berkembang sejak awal mula diperkenalkan. Selain itu, jenis tanaman yang digunakan juga semakin beragam. Pada tulisan ini, akan diulas empat hal penting mengenai PMFC. Hal pertama yakni mengenai proses dasar pada teknologi P-MFC dan jenis tanaman P-MFC. Kedua mengenai variasi desain P-MFC dan efektifitasnya dalam menghasilkan listrik. Ketiga, tentang potensi PMFC di Indonesia, dan terakhir mengenai tantangan utama dalam aplikasi P-MFC.

Kata kunci: energi terbarukan, listrik, mikroba, P-MFC, sel bahan bakar

\section{PENDAHULUAN}

Listrik telah menjadi kebutuhan utama bagi masyarakat Indonesia. Kebutuhan listrik terus meningkat setiap tahun, dan diprediksikan permintaan litrik pada tahun 2025 akan meningkat sebesar 11-12\% (OEI, 2019). Sayangnya pada permintaan yang besar tersebut, sumber energi penghasil listrik masih menggunakan bahan bakar fosil. Ditahun 2018 
tercatat bahwa sumber listrik berasal dari batu bara sebesar $50 \%$, gas bumi sebesar 29\%, bahan bakar minyak sebesar 7\% dan energi terbarukan sebesar 14\% (OEI, 2019). Sebagaimana kita tahu bahwa banyak negara tengah berusaha meminimalisir penggunaan energi fosil dikarenakan efek negatifnya terhadap lingkungan dan manusia (Pimentel, 2014), termasuk Indonesia. Melalui Perpres No. 4 tahun 2016 tentang Percepatan Pembangunan Infrastruktur Ketenagalistrikan, pemerintah berusaha untuk mempercepat pelaksanaan pemanfaatan energi terbarukan. Salah satu jenis energi terbarukan yang mungkin dikembangkan di Indonesia adalah Sel Bahan Bakar Berbasis Mikroba-Tanaman (P-MFC).

P-MFC masuk dalam jajaran teknologi baru yang memanfaatkan aktifitas biokimia tanaman untuk memproduksi listrik. Teknologi ini diperkenalkan pada tahun 2008 (Strik, 2008a) dan mampu menghasilkan listrik menggunakan tanaman sejenis rerumputan (Reed mannagrass). P-MFC diklaim sebagain teknologi yang ramah lingkungan dan sustainable karena dalam proses operasi, sama sekali tidak menghasilkan emisi. Listrik dihasilkan dari aliran elektron simultan melalui anoda dan katoda pada sistem dan selanjutnya produk yang dihasilkan selain listrik adalah air (Nitisoravut \& Regmi, 2017). Elektron dihasilkan dari hasil degradasi bahan organik yang sebelumnya dilakukan oleh mikroba, khususnya mikroorganisme yang aktif secara elektrokimia (Strik et al., 2011). Mikroba tersebut hidup secara alamiah di sekitar perakaran tanaman atau dikenal sebagai area rhizosphere (Neori, 2000). Bahan organik di area rhizosphere diperoleh dari tanaman yang melakukan eksudasi atau membuang kelebihan bahan organik hasil fotosintesis melalui akar. Secara umum, lahan basah akan sangat baik bagi PMFC, karena kondisi tergenang akan membantu terjadinya pertukaran ion pada sirkuit penghasil listrik (Wetser \& Liu, 2015).

Untuk dapat mengimplementasikan teknologi PMFC dengan baik, maka dibutuhkan informasi mengenai prinsip kerja P-MFC dan potensinya. Pada tulisan ini akan diulas secara rinci prosesproses dasar pada teknologi P-MFC, bermacam desain P-MFC pada berbagai penelitian dan kaitannya dengan daya listrik yang mampu dihasilkan, serta tantangan implementasi P-MFC.

\section{PROSES DASAR P-MFC}

Proses fotosintesis menjadi hal mendasar dalam P-MFC. Tanaman berklorofil mengubah energi matahari menjadi energi kimia berbentuk bahan organik. Dalam hal ini bahan organik berbentuk karbohidrat $\left(\mathrm{CH}_{2} \mathrm{O}\right)$, yang merupakan produk dari reaksi antara air dan karbon dioksida (seperti ditunjukkan pada Reaksi 1). Tanda positif pada energi bebas Gibbs ( $\left.G^{\circ}\right)$ menandakan bahwa reaksi berlangsung secara endoterm dan membutuhkan energi. Energi tersebut didapatkan dari sinar matahari (Johnson, 2016).

$\mathrm{CO}_{2}+\mathrm{H}_{2} \mathrm{O}+$ cahaya matahari $\rightarrow \mathrm{CH}_{2} \mathrm{O}+\mathrm{O}_{2} \quad \mathrm{G}^{\mathrm{o}}=+479$ $\mathrm{kJ} / \mathrm{mol}$

Sebagian hasil konversi energi matahari, selain dimanfaatkan sebagai bahan makanan dan oksigen bagi manusia, juga terbuang melalui sel akar tanaman (exudates) dalam bentuk bahan organik karbon (Grayston \& Vaughan, 1997). Pelepasan bahan organik berpengaruh besar pada ketersediaan nutrisi di area rhizosphere atau sekitar daerah perakaran dan juga mempengaruhi keberadaan komunitas mikroba tanah (Paterson, 2003). Tanaman mampu membuang komponen yang berefek langsung pada kandungan ekspresi gen mikroba, sehingga jenis mikroba tanah pada masing-masing jenis tanaman akan mendukung pertumbuhkan biologis tanaman inang (Paterson, 2003). Selain bersumber dari eksudasi akar, bahan organik di rhizosphere juga diperoleh dari pembusukan akar tanaman mati (lysate). Pada tanaman budidaya (contoh: padi), sisa tanaman yang berasal dari siklus panen sebelumnya, keberadaan alga dan penambahan kompos/ pupuk organik juga dapat dikategorikan sebagai sumber input bahan organik (Roger \& Watanabe, 1984).

Pada lahan basah, mikroorganisme memanfaatkan bahan organik untuk proses metabolisme tubuhnya (Cheng \& Gershenson, 2007). Salah satunya yakni sebagai donor elektron pada proses respirasi. Mikroba mengubah karbon organik melalui dua reaksi 
dekomposisi berbeda, yakni secara aerobik dan anaerobik. Reaksi aerobik, terjadi di permukaan air yang kaya oksigen, sedangkan pada kedalaman air dengan kondisi oksigen terbatas, dekomposisi dilakukan secara anaerobik. Pada dekomposisi anaerobik, proses hidrolisis mengubah bahan organik kompleks seperti karbohidrat dan protein menjadi monomernya. Lalu, monomer tersebut (gula dan asam amino), melalui degradasi oleh mikroorganisme fermentasi, diubah menjadi alkohol dan asam lemak. Lebih lanjut, hasil fermentasi didegradasi oleh mikroorganisme menghasilkan dekomposisi senyawa berupa karbondioksida, elektron dan proton, yang kemudian didonasikan kepada anoda pada P-MFC untuk menghasilkan listrik (Strik et al., 2011).

Disebutkan bahwa mikroba di sekitar perakaran tanaman memiliki aktivitas 10 kali lebih besar dibandingan di lokasi tanah lainnya (Cheng \& Liu, 2006). Kompleksnya campuran senyawa yang tersedia cukup menyulitkan dalam menentukan substrat yang sebenarnya dioksidasi oleh mikroorganisme pada sistem P-MFC. Sebagai model, asetat digunakan sebagai ilustrasi degradasi yang dilakukan oleh mikroba (Helder, 2012b), seperti ditunjukkan dalam Reaksi 2, sebagai berikut:

$$
\mathrm{CH}_{3} \mathrm{COO}^{-}+4 \mathrm{H}_{2} \mathrm{O} \rightarrow 2 \mathrm{HCO}_{3}^{-}+9 \mathrm{H}^{+}+8 \mathrm{e}^{-}
$$

Elektron yang dihasilkan dari degradasi bahan organik oleh mikroorganisme, dioksidasi di anoda pada P-MFC (Gambar 1). Dengan adanya koneksi kepada katoda yang memanfaatkan senyawa yang memiliki potensial sel yang lebih tinggi, maka energi akan dapat dipanen (Helder, 2012c). Selanjutnya, reaksi yang terjadi di katoda adalah reduksi oksigen menjadi air. Oksigen memiliki standar potensial sel yang cukup tinggi (Tabel 1) dan tersedia cukup banyak di sekitar katoda (oleh sebab itu katoda harus bersentuhan dengan udara luar). Oksigen teroksidasi sesuai dengan setengah reaksi pada Reaksi 3 berikut: Reaksi 3 menunjukkan hasil sampingan dari P-MFC, yakni air (Schlesinger \& Bernhardt, 2013).

$\mathrm{O}_{2}+4 \mathrm{H}^{+}+4 \mathrm{e}^{-} \rightarrow 2 \mathrm{H}_{2} \mathrm{O}$

Apabila jumlah oksigen menipis, maka penerima elektron akan menyesuaikan dengan keberadaan senyawa lain, misalnya: denitrifikasi pada nitrat, reduksi besi, reduksi sulfat atau reduksi karbondioksida (Tabel 1). Sebagai contoh, bakteri denitrifikasi akan mereduksi nitrat $\mathrm{NO}_{3}{ }^{-}$ ) menjadi gas nitrogen, melalui Reaksi 4. Bakteri ini juga mampu menggunakan monomer hasil fermentasi sebagai donor elektron pada anoda. Secara umum, dapat diingat bahwa elektron yang dihasilkan pada oksidasi bahan organik di anoda akan ditransfer menuju katoda melalui kawat

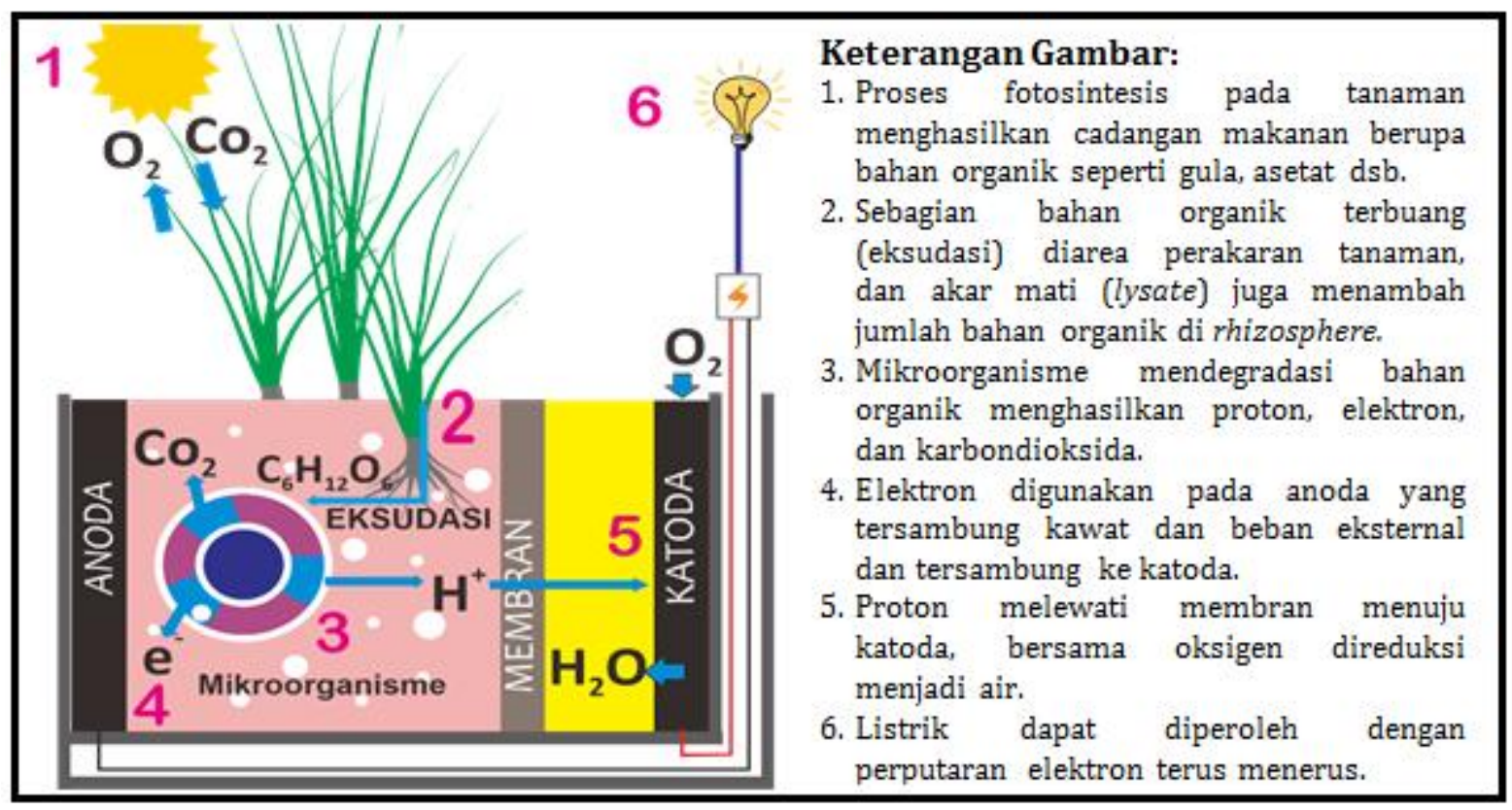

Gambar 1. Ilustrasi Desain sederhana P-MFC 
Tabel 1. Daftar Senyawa Penerima Elektron, Reaksi Total dan Nilai Gibbs Free Energi*

\begin{tabular}{lll}
\hline \multicolumn{1}{c}{ Senyawa } & \multicolumn{1}{c}{ Reaksi redoks kesuluruhan pada anoda dan katoda } & \multicolumn{1}{c}{$\boldsymbol{\Delta} \mathbf{G}^{\mathbf{0}}$} \\
\hline $\mathrm{O}_{2}$ & {$\left[\mathrm{CH}_{2} \mathrm{O}\right]+\mathrm{O}_{2} \rightarrow \mathrm{CO}_{2}+\mathrm{H}_{2} \mathrm{O}$} & $-502 \mathrm{~kJ} / \mathrm{mol}$ \\
$\mathrm{NO}_{3}{ }^{-}$ & {$\left[\mathrm{CH}_{2} \mathrm{O}\right]+0.8 \mathrm{NO}_{3}+3.8 \mathrm{H}^{+} \rightarrow \mathrm{CO}_{2}+0,4 \mathrm{~N}_{2}+1.4 \mathrm{H}_{2} \mathrm{O}$} & $-474 \mathrm{~kJ} / \mathrm{mol}$ \\
$\mathrm{FeOOH}$ & {$\left[\mathrm{CH}_{2} \mathrm{O}\right]+4 \mathrm{FeOOH}+6 \mathrm{H}^{+} \rightarrow \mathrm{FeCO}_{3}+3 \mathrm{Fe}^{2+}+6 \mathrm{H}_{2} \mathrm{O}$} & $-24,3 \mathrm{~kJ} / \mathrm{mol}$ \\
$\mathrm{SO}_{4}{ }^{2-}$ & {$\left[\mathrm{CH}_{2} \mathrm{O}\right]+0.5 \mathrm{SO}_{4}{ }^{2-}+0.5 \mathrm{H}^{+} \rightarrow 0.5 \mathrm{HS}^{-}+\mathrm{CO}_{2}+\mathrm{H}_{2} \mathrm{O}$} & $-18 \mathrm{~kJ} / \mathrm{mol}$ \\
$\mathrm{CO}_{2}$ & $\mathrm{CO}_{2}+\mathrm{H}_{2} \rightarrow \mathrm{CH}_{4}+\mathrm{H}_{2} \mathrm{O}$ & $-17,4 \mathrm{~kJ} / \mathrm{mol}$ \\
\hline
\end{tabular}

*(Schlesinger \& Bernhardt, 2013)

dan power consumer. Kemudian di katoda, terjadi reduksi oksigen (Cheng \& Liu, 2006).

$$
2 \mathrm{NO}_{3}^{-}+10 \mathrm{e}^{-}+12 \mathrm{H}^{+} \rightarrow \mathrm{N}_{2}+6 \mathrm{H}_{2} \mathrm{O}
$$

Sebuah sistem sel bahan bakar mikroba atau Microbial Fuel Cell (MFC), secara teoritis memiliki voltase (emf cell) sebesar 1,101 V. Nilai tersebut diperoleh dari perhitungan menggunakan senyawa asetat $\left(\mathrm{CH}_{3} \mathrm{COO}^{-)}\right.$yang dioksidasi pada anoda dan senyawa oksigen $\left(\mathrm{O}_{2}\right)$ yang direduksi pada katoda. Sel Emf dihitung dengan cara mengurangi potensial sel pada katoda dan anoda (Logan et al., 2006) atau pengurangan nilai potensial reduksi terhadap nilai potensial oksidasi, sesuai Persamaan 5 berikut :

$$
\begin{aligned}
& E_{\text {emf }}=E_{\text {cat }}-E_{\text {an }} \\
& E_{\text {an }}=E_{\text {an }}^{\circ}-\frac{R T}{n F} \ln \left(\frac{\left[\mathrm{CH}_{3} \mathrm{COO}^{-}\right]}{\left[\mathrm{H}^{+}\right]^{9} *\left[\mathrm{HCO}^{3-}\right]^{2}}\right) \\
& E_{\text {cat }}=E_{\text {cat }}^{\circ}-\frac{R T}{n F} \ln \left(\frac{1}{p \mathrm{O}_{2}\left[\mathrm{H}^{+}\right]^{4}}\right)
\end{aligned}
$$

Dengan penggunaan Hukum Nerst, nilai potensial teoritis pada anoda dapat diprediksi, yakni dengan menggunakan persamaan 6 . Konsentrasi seluruh spesi senyawa sesuai Hukum Nerst sebesar 1 Molar, $\mathrm{E}_{\mathrm{an}}=$ potensial anoda (Volt), $\mathrm{E}_{\text {an }}^{\circ}=$ potensial standar anoda pada kondisi standar $\left(25^{\circ} \mathrm{C}\right), \mathrm{R}=$ konstanta gas Avogadro (8,314 J/mol/K), $\mathrm{n}=$ jumlah elektron yang berperan, $8 \mathrm{e}^{-}$(Persamaan 2$), \mathrm{F}=$ konstanta Faraday $(96.500 \mathrm{C} / \mathrm{mol})$ dan $\mathrm{T}=$ suhu dalam kelvin. Selanjutnya, nilai potensial teoritis pada katoda dihitung juga dengan persamaan Nerst seperti ditunjukkan oleh Persamaan 7. Dimana, $\mathrm{E}_{\text {cat }}=$ potensial katoda (Volt), $\mathrm{E}_{\text {cat }}^{o}=$ potensial katoda standar, $\mathrm{R}=$ konstanta gas Avogadro $(8,314$ $\mathrm{J} / \mathrm{mol} / \mathrm{K}), \mathrm{n}=$ jumlah elektron yang berperan, 4e- (Persamaan 3), F= konstanta Faraday (96.500 Coloumb/mol), $\mathrm{T}=$ Suhu dalam Kelvin (298K), $\mathrm{pO}_{2}=$ tekanan parsial (pascal), $\left[\mathrm{H}^{+}\right]=$ konsentrasi $\mathrm{H}^{+}$dalam molar (mol/L) (Logan et al., 2006). Namun pada praktiknya, nilai faktual yang diukur secara langsung tidak akan mencapai nilai teoritis tersebut, tetapi lebih rendah. Perbedaan ini terjadi karena adanya kehilangan energi atau lebih dikenal dengan istilah overpotentials yang terjadi di elektroda (Logan et al., 2006).

\section{JENIS TANAMAN YANG DIGUNAKAN PADA P-MFC}

Tanaman yang digunakan untuk membangun desain P-MFC sangat beragam. Beberapa variasi tanaman dipilih sebagai model desain, salah satunya karena mudah didapat secara lokal dan dapat hidup secara anaerobik atau tergenang air (Strik, 2008a). Berdasarkan jenis fotosintesisnya, tanaman yang digunakan terbagi menjadi dua yakni C3 dan C4 (Nitisoravut \& Regmi, 2017). Diantara kedua jenis tanaman tersebut, C4 dipercayai memiliki performa yang lebih baik dibandingkan dengan C3 karena C4 mampu mengkonversi cahaya matahari dengan efisiensi yang lebih baik. Secara teoritis, nilai efisiensi konversi maksimum untuk jenis tanaman C4 adalah $6 \%$ dan untuk C3 adalah sebesar 4,6\% (Wang \& Guo, 2012).

Beberapa contoh tanaman yang digunakan sebagai model dalam penelitian disajikan dalam Tabel 2. Densitas listrik (power density) yang dihasilkan sangat bervariasi, yakni antara 6 $222 \mathrm{~mW} / \mathrm{m}^{2}$. Selain dipengaruhi oleh jenis 
tanaman, lokasi pengoperasian, jenis larutan nutrisi yang digunakan, jenis elektroda dan beberapa perlakuan yang berbeda juga berpengaruh dalam menghasilkan keluaran listrik bio.

\section{VARIASI DESAIN P-MFC}

Berbagai macam penelitian dilakukan untuk meningkatkan produksi energi pada P-MFC. Desain yang dipergunakan oleh para peneliti pun beragam, sesuai dengan tujuan penelitian. Secara umum, sebuah desain P-MFC terdiri dari: wadah reaktor, tanaman, media nutrisi, elektroda karbon (anoda dan katoda), membran, kawat penghantar, dan beban internal, seperti ditunjukkan pada Gambar 1.

4.1.P-MFC Berbentuk Silinder (cylindrical) Pada P-MFC berbentuk silinder, seperti Gambar 2 (M. Helder et al., 2010), sebuah Plexiglas silinder dilengkapi dengan membran (diameter 9,9 cm) digunakan sebagai wadah utama. Biji grafit $(<1 \mathrm{~mm})$ disebar pada dasar gelas sebagai anoda yang juga digunakan sebagai media hidup akar tanaman. Larutan Hoagland berfungsi sebagai sumber nutrisi (Taiz \& Zeiger, 2006) dituangkan pada kompartemen anoda setinggi $19 \mathrm{~cm}$.

Tanaman yang digunakan adalah S. anglica, $A$. anomala dan A. donax. S. Silinder anoda tersebut, lalu dimasukkan ke dalam kompartemen katoda (diameter $12 \mathrm{~cm}$ ) yang terdiri dari gelas beaker dimana graphite felt diletakkan di dasar kompartemen. Graphite rod diletakkan diantara biji graphite (anoda) sebagai pengumpul arus, kemudian kawat emas dipasangkan pada rod untuk kemudian diberikan beban (1000 Ohm) lalu dikoneksikan ke katoda dengan cara dipilin pada kain grafit katoda. Lalu, Potensial arus listrik diukur menggunakan multimeter dan Fieldpoint

Tabel 2. Variasi Jenis Tanaman yang Digunakan dalam Beberapa Desain P-MFC

\begin{tabular}{|c|c|c|c|c|}
\hline Jenis Tanaman & Jenis Fotosintesis & $\begin{array}{l}\text { Lokasi } \\
\text { Operasi }\end{array}$ & Power Density & Referensi \\
\hline Oriza sativa & C3 & Sawah garapan & $6-80\left(\mathrm{~mW} / \mathrm{m}^{2}\right)$ & $\begin{array}{l}\text { Kaku (2008), } \\
\text { Sudirjo (2020) }\end{array}$ \\
\hline Typha latifolia & $\mathrm{C} 3$ & $\begin{array}{l}\text { Lahan rawa } \\
\text { buatan }\end{array}$ & $6,12\left(\mathrm{~mW} / \mathrm{m}^{2}\right)$ & Oon et al. (2015) \\
\hline Spartina anglica & $\mathrm{C} 4$ & $\begin{array}{l}\text { Ruang iklim } \\
\text { terkontrol }\end{array}$ & $222\left(\mathrm{~mW} / \mathrm{m}^{2}\right)$ & $\begin{array}{l}\text { M. Helder et al. } \\
(2010)\end{array}$ \\
\hline Glyceria maxima & C3 & $\begin{array}{l}\text { Ruang iklim } \\
\text { terkontrol }\end{array}$ & $67\left(\mathrm{~mW} / \mathrm{m}^{2}\right)$ & Strik (2008a) \\
\hline Canna indica & $\mathrm{C} 4$ & $\begin{array}{l}\text { Lahan rawa } \\
\text { buatan }\end{array}$ & $18\left(\mathrm{~mW} / \mathrm{m}^{2}\right)$ & Lu (2015) \\
\hline $\begin{array}{c}\text { Euphyllia } \\
\text { glabrescens }\end{array}$ & $\mathrm{C} 4$ & $\begin{array}{l}\text { Ruang iklim } \\
\text { terkontrol }\end{array}$ & $0,088 \mathrm{GJ} / \mathrm{ha} / \mathrm{th}$ & $\begin{array}{l}\text { Bombelli et al. } \\
\text { (2013) }\end{array}$ \\
\hline
\end{tabular}

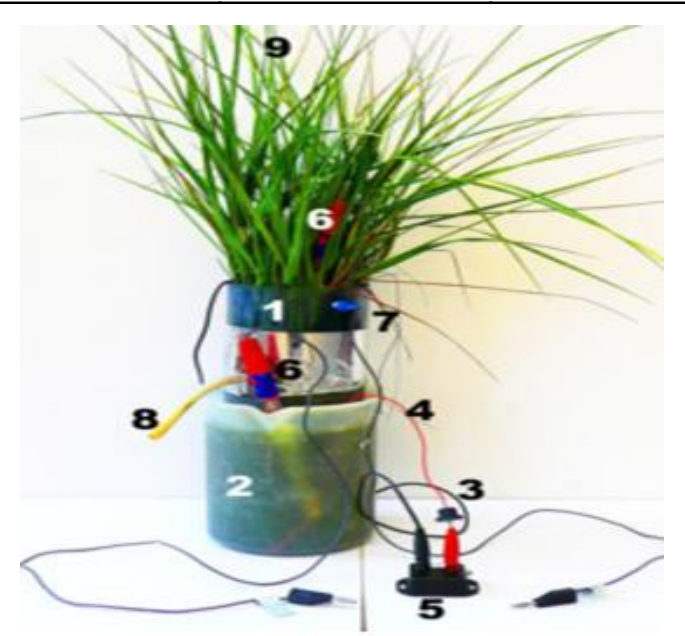

Gambar 2. Desain P-MFC Silinder. Dimana 1: Anoda, 2: Katoda, 3 dan 4: Kawat Emas, 5: Beban Internal, 6 dan 7: Media Nutrisi, 9: Tanaman Spartina Anglica (M. Helder et al., 2010) 
(Module S, national instrument). Pengambilan data dilakukan selama 26 minggu skala laboratorium. Pada desain P-MFC silinder ini, diperoleh maksimum densitas energi sebesar 222 $\mathrm{mW} / \mathrm{m}^{2}$ yakni berasal dari tanaman $S$. Anglica (M. Helder et al., 2010).

\subsection{P-MFC Berbentuk Pelat Datar (Flat Plat)}

Pada desain pelat datar, terdapat dua kompartemen yakni anoda dan katoda. Kompartemen anoda berdimensi 18x18x2 cm dan terdapat tiga bagian graphite felt yang terpisah, masing-masing setinggi $5 \mathrm{~cm}$. Kawat emas digunakan sebagai pengumpul elektron pada anoda dan katoda. Kompartemen katoda dan anoda dipisahkan oleh membran (cation exchange membrane). Graphite felt setinggai 5 $\mathrm{cm}$ juga digunakan pada katoda, dengan 3 bagian yang masing-masing terhubung ke anoda (Gambar 3).

Kompartmen katoda terdiri dari dua modul aliran dimana graphite felt diletakkan ditengahnya (Helder, 2012a, 2012b). Selanjutnya larutan nutrisi diberikan secara berkala dari dasar reaktor. Sistem ini disimpan dalam ruangan dengan cuaca terkontrol. Ditemukan dalam penelitian ini bahwa, densitas energi mampu ditingkatkan hingga 250\% dengan mengganti nitrat menjadi ammonium karbonat sebagai nutrisi tanaman (Helder, 2012b).

\subsection{P-MFC Berbentuk Tubular}

Bentuk P-MFC tubular dapat di-implementasikan secara langsung di area lahan basah tanpa, seperti di persawahan, atau rawa lahan basah, maupun lahan basah buatan - constructed wetlands (Lu, 2015; Sudirjo, 2020; Wetser \& Liu, 2015). Pada lahan buatan, digunakan wadah box berbahan polypropylene dengan dimensi 1.2 x1.0x1.0 $\mathrm{m}^{3}$ (Wetser \& Liu, 2015). Reaktor didesain berbentuk menyerupai pipa besar memanjang yang terdiri dari: selang silikon dibagian paling dalam, katoda graphite felt yang dililit pada selang, lalu ditambahkan dengan membran yang juga dililit setelah katoda dan terakhir yakni anoda graphite felt yang juga dililit pada bagian paling luar (Wetser, 2017), seperti ditunjukkan oleh Gambar 4.
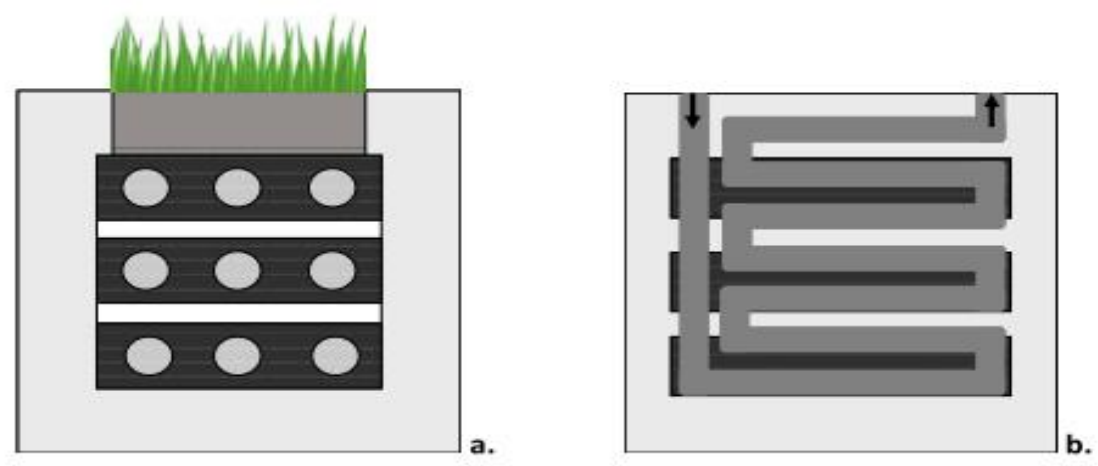

Gambar 3. (a) Anoda dan (b) katoda pada Desain P-MFC Pelat Datar dengan Bagian Atas, Tengah, dan Dasar (Helder, 2012b)
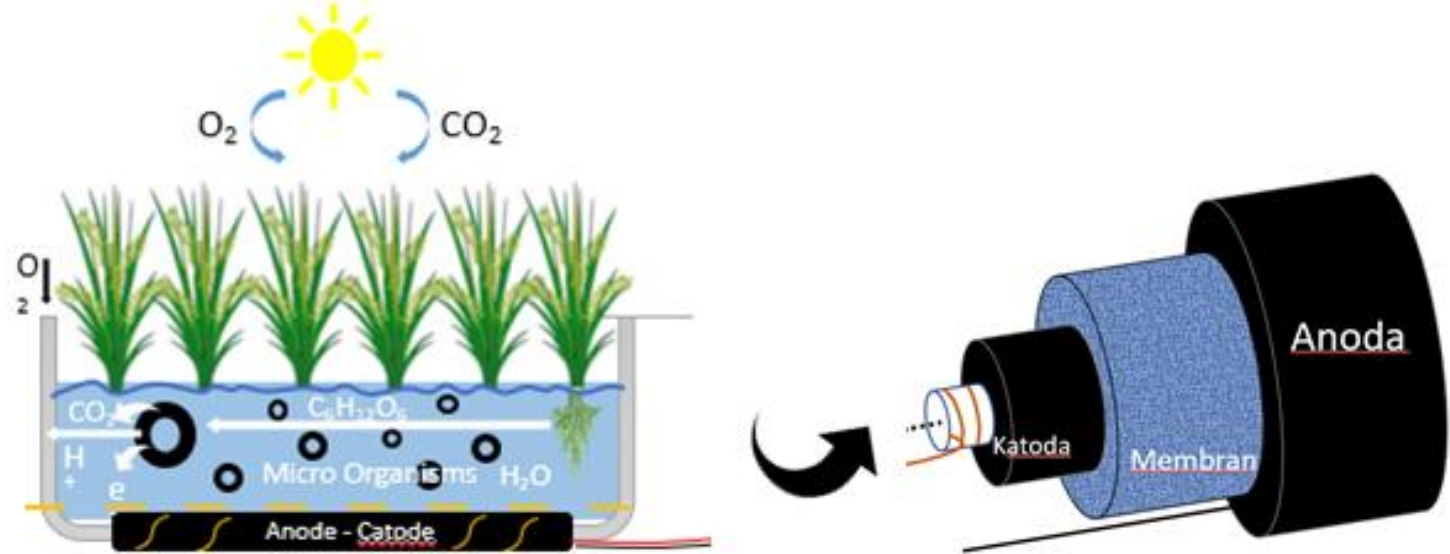

Gambar 4. Ilustrasi Desain P-MFC Berbentuk Tubular 
Anoda dan katoda menggunakan graphite felt setebal $3 \mathrm{~mm}$, dengan dimensi panjang dan lebar 210x90 mm. Membran diberi lubang sebanyak 5 buah dengan diameter $1 \mathrm{~mm}$ demi memberi ruang untuk mikroba berpindah dari anoda ke katoda. Stik grafit digunakan pada anoda sebagai kolektor arus, sedangkan kawat emas digunakan pada katoda untuk menghantarkan arus. Selang silicon memiliki ketebalan $0.9 \mathrm{~m}$ dan diameter dalam sebesar $6 \mathrm{~mm}$. Selang berbahan silikon sengaja dipilih agar oksigen dapat masuk ke dalam reaktor. Tidak ada tambahan nutrisi atau elektrolit diberikan pada desain ini. P-MFC berbentuk tubular kemudian dipasang sedalam $10 \mathrm{~cm}$ dari permukaan air dengan kedua ujung selang tetap bersentuhan dengan udara luar. Beban internal yang digunakan bervariasi, yakni sebesar $1000 \mathrm{ohm}, 2000 \mathrm{ohm}, 4000 \mathrm{ohm}$ hingga $16.000 \mathrm{ohm}$. Tambahan udara dengan kandungan $\mathrm{O}_{2}$ murni dipompa kedalam selang silikon untuk memastikan terdapat oksigen yang cukup untuk direduksi di katoda.

\section{POTENSI P-MFC DI INDONESIA}

Indonesia memiliki potensi yang baik dalam mengembangkan P-MFC mengingat luasnya lahan tergenang yang dimiliki, baik sawah garapan maupun lahan rawa, gambut, danau, dsb. Selain itu, cahaya matahari tersedia sepanjang tahun, sehingga proses fotosintesis pada tanaman relatif tidak terkendala oleh musim. Potensi lahan tergenang tersebut dapat diprediksi dengan memperhatikan jumlah metana yang teremisi dari suatu lahan basah. Produksi metana dapat dievaluasi sebagai mikroorganisme elektrokimia aktif yang berhasil berkompetisi dengan bakteri metanogen untuk memperoleh elektron. Sehingga, arus listrik dapat diprediksi dengan mengatahui rata-rata produksi metana (Wetser, 2016). Perhitungan potensi arus berdasarkan produksi metana, menggunakan Persamaan 8, berikut:

$$
P=\frac{J * n * F * U}{M * t}
$$

Dimana, P adalah Potensi listrik (TW, terawatt), J adalah produksi metana $(\mathrm{Tg} / \mathrm{th}), \mathrm{n}$ adalah jumlah elektron pada degradasi asetat (8e-), $\mathrm{F}$ adalah konstanta Faraday (96.500 A s/mol), U adalah prediksi arus yakni sebesar $0,6 \mathrm{~V}$ (berdasarkan hasil terbaik pada penelitian P-MFC (Wetser, 2016) di lokasi penelitian tanah gambut), $M$ adalah massa relative metana ( $16 \mathrm{gram} / \mathrm{mol}$ ) dan $\mathrm{t}$ adalah jumlah detik dalam satu tahun (s/th).

Luas lahan sawah Indonesia yang berhasil dipanen pada tahun 2019 adalah seluas 10,6 juta hektar (BPS, 2020). Sedangkan luas lahan gambut nasional adalah seluas 38,3 juta hektar (Husaini, 2012). Jika ditotal maka akan diperoleh angka sebesar 48,9 juta hektar lahan basah yang bersumber dari sawah dan lahan gambut. Emisi metana dari lahan sawah diestimasi sebesar $30 \mathrm{mg} / \mathrm{m}^{2} / \mathrm{jam}$. Sedangkan pada lahan gambut diestimasi sebesar $1.260 \mathrm{~kg} /$ ha/yr (IPCC). Nilai-nilai ini kemudian dikonversi menjadi emisi dalam satuan tera gram per tahun ( $\mathrm{Tg} / \mathrm{th}$ ), seperti ditunjukkan pada Tabel 3.

Selanjutnya, setelah memasukkan nilai emisi metana ke dalam Persamaan 8, maka didapati potensi listrik pada lahan padi yakni sebesar 0,026 TW dan pada lahan gambut sebesar 0,044 TW. Dan bila dijumlahkan, makan total potensi listrik P-MFC keseluruhan nasional yang bersumber dari lahan padi dan gambut adalah sebesar 0,07 TW. Nilai perhitungan tersebut setara dengan 0,0267 \% dari total listrik yang mampu dibangkitkan secara nasional, 262.661 GW (BPS, 2018). Nilai potensial P-MFC tersebut senilai dengan 46 kali lebih besar dari total nasional kapasitas terpasang pembangkit listrik tenaga panas bumi pada tahun 2017 (BPS, 2018).

\section{TANTANGAN IMPLEMENTASI P-MFC}

Overpotensial atau kehilangan energi adalah tantangan besar dari implementasi P-MFC. Overpotensial terjadi di elektroda disebabkan oleh beberapa faktor, yakni: kehilangan saat proses aktivasi (activation losses), kehilangan pada proses metabolisme bakteri (bacteria metabolic losses), dan kehilangan saat perpindahan massa (mass transport losses) (Logan et al., 2006).

Energi aktivasi dibutuhkan di awal proses redoks. Hilang energi di proses aktivasi dapat terjadi pada dua kondisi: 1) saat elektron berpindah dari bahan organik ke anoda atau, 2) saat elektron berpindah dari katoda ke oksigen sebagai penerima elektron. Kehilangan ini dapat 
Tabel 3. Potensi P-MFC pada Lahan Sawah dan Gambut Indonesia

\begin{tabular}{cccc}
\hline Lahan & Luas Lahan (ha) & Emisi metana (Tg/th) & Potensi (TW*) \\
\hline Padi & 10.667 .887 & 28,04 & 0,026 \\
Gambut & 38.317 .000 & 48,28 & 0,044 \\
\hline \multicolumn{5}{c}{ Total } & & 0,070
\end{tabular}

*Potensi dalam Tera Watt $\left(10^{12}\right.$ Watt $)$

disiasati salah satunya dengan memperluas permukaan elektroda, meningkatkan suhu operasi, dan menambahkan sifat biofilm pada elektroda (Strik, 2008b).

Selanjutnya, kehilangan pada proses metabolisme terjadi apabila mikroba mendapatkan energi metabolik tinggi dan sebaliknya sistem P-MFC hanya mendapatkan energi rendah. Pada bakteri, untuk memperoleh energi metabolik, ada perpindahan elekton dari substrat ke senyawa oksidator dengan potensial tinggi. Pada P-MFC anoda berperan sebagai oksidator. Semakin tinggi perbedaan potensial redoks antara substrat dan anoda, maka bakteri berpotensi mendapatkan energi yang lebih tinggi. Sehingga, potensial anoda harus diupayakan dalam kondisi rendah (negatif) untuk memastikan P-MFC mendapatkan energi yang lebih besar. Akan tetapi, bila potensial anoda terlalu rendah juga berbahaya karena dapat menghalangi perpindahan transport elektron (Logan et al., 2006). Belum ada solusi dapat mengatasi permasalahan ini secara signifikan.

Kehilangan perpindahan massa diakibatkan oleh rendahnya kecepatan perpindahan spesi senyawa-senyawa kimia menuju elektroda, (Logan et al., 2006) dan hal ini dipengaruhi oleh jumlah bahan organik yang terdegradasi di rhizosphere (Helder, 2012b).

\section{KESIMPULAN}

Lahan basah yang luas dan sinar matahari yang bersinar sepanjang tahun menjadikan Indonesia sebagai lokasi yang baik dalam pengembangan teknologi P-MFC. Selain itu, nilai potensi energi P-MFC secara nasional terhitung cukup besar, yakni senilai 0.07 TW per tahun. Nilai tersebut setara 46 kali lebih besar dari listrik yang dihasilkan oleh panas bumi tahun 2017. Desain yang banyak digunakan untuk penelitian P-MFC sejauh ini yakni desain berbentuk silinder, pelat datar dan tubular. Keberadaan bahan organik dan nutrisi tanaman di area rhizodeposit sangat menunjang kehidupan mikroorganisme penghasil listrik. Namun, tantangan yang masih menjadi momok bagi implementasi P-MFC adalah besarnya kemungkinan energi yang hilang saat proses aktivasi, metabolisme bakteri dan perpindahan massa senyawa kimia ke elektroda.

\section{Ucapan Terima Kasih}

Penulis mengucapkan terimakasih kepad Hibah Penelitian Unggulan ITERA dengan nomor kontrak B/350/IT9.C1/PT.01.03/2019 yang telah mendukung penelitian ini.

\section{DAFTAR PUSTAKA}

Bombelli, P., Iyer, D. M. R., Covshoff, S., McCormick, A. J., Yunus, K., Hibberd, J. M., Howe, C. J. (2013). Comparison of power output by rice (Oryza sativa) and an associated weed (Echinochloa glabrescens) in vascular plant biophotovoltaic (VP-BPV) systems. Applied Microbiology and Biotechnology, 97(1), 429-438.

BPS. (2018). Statistik Listrik 2012-2017. In B. P. Statistik (Ed.), (pp. 22). Jakarta.

BPS. (2020). Luas Panen, Produksi, dan Produktivitas Padi Menurut Provinsi, 2018-2019. Retrieved from https:// www.bps.go.id/dynamictable/2019/04/ 15/1608/luas-panen-produksi-danproduktivitas-padi-menurut-provinsi2018.html

Cheng, \& Gershenson. (2007). Carbon fluxes in the rhizosphere The Rhizosphere (pp. 31-56): Elsevier. 
Cheng, \& Liu. (2006). Increased performance of single-chamber microbial fuel cells using an improved cathode structure. Electrochemistry communications, 8(3), 489-494.

Grayston, S. J., \& Vaughan, D. (1997). Rhizosphere carbon flow in trees, in comparison with annual plants: the importance of root exudation and its impact on microbial activity and nutrient availability. Applied Soil Ecology, 5(1), 2956. doi:https://doi.org/10.1016/S09291393(96)00126-6.

Helder. (2012a). The flat-plate plant-microbial fuel cell: the effect of a new design on internal resistances. Biotechnology for biofuels, 5(1), 70.

Helder. (2012b). New plant-growth medium for increased power output of the plantmicrobial fuel cell. Bioresource Technology, 104, 417-423.

Helder. (2012c). Phd Dissertation, Design Criteria for PMFC. Wageningen.

Helder, M., Strik, D., Hamelers, H., Kuhn, A., Blok, C., \& Buisman, C. (2010). Concurrent bioelectricity and biomass production in three Plant-Microbial Fuel Cells using Spartina anglica, Arundinella anomala and Arundo donax. Bioresource Technology, 101(10), 3541-3547.

Husaini, M. (2012). Pengkajian Daya Saing dan Dampak Kebijakan Terhadap Usahatani Padi dan Jeruk Lahan Gambut Kabupaten Barito Kuala Kalimantan Selatan. AGRIDES: Jurnal Agribisnis Perdesaan, 2(2), 9243.

Johnson, M. P. (2016). Photosynthesis. Essays in biochemistry, 60(3), 255-273. doi:10.1042/EBC20160016

Kaku, N. (2008). Plant/microbe cooperation for electricity generation in a rice paddy field. Applied Microbiology and Biotechnology, 79(1), 43-49.
Logan, B. E., Hamelers, B., Rozendal, R., Schröder, U., Keller, J., Freguia, S., . . Rabaey, K. (2006). Microbial Fuel Cells:

Methodology and Technology. Environmental Science \& Technology, 40(17), 5181-5192. doi:10.1021/ es0605016

Lu, l. (2015). Microbial community structure accompanied with electricity production in a constructed wetland plant microbial fuel cell. Bioresource Technology, 195, 115-121.

Neori, A. (2000). Bioactive chemicals and biological-biochemical activities and their functions in rhizospheres of wetland plants. The Botanical Review, 66(3), 350-378.

Nitisoravut, R., \& Regmi, R. (2017). Plant microbial fuel cells: A promising biosystems engineering. Renewable and Sustainable Energy Reviews, 76, 81-89. doi:http://doi.org/10.1016/ j.rser.2017.03.064

OEI. (2019). Outlook Energi Indonesia 2019. Retrieved from https://www.esdm.go.id/ assets/media/content/content-outlookenergi - indonesia-2019-bahasaindonesia.pdf

Oon, Y.-L., Ong, S.-A., Ho, L.-N., Wong, Y.-S., Oon, Y.-S., Lehl, H. K., \& Thung, W.-E. (2015). Hybrid system up-flow constructed wetland integrated with microbial fuel cell for simultaneous wastewater treatment and electricity generation. Bioresource Technology, 186, 270-275.

Paterson, E. (2003). Importance of rhizodeposition in the coupling of plant and microbial productivity. European Journal of Soil Science, 54(4), 741-750. doi:10.1046/j.1351-0754.2003.0557.x

Pimentel, D. (2014). Implications for the Economy and Environment of Alternatives to Fossil-Fuel Energy. In J. E. Gates, D. L. Trauger, \& B. Czech (Eds.), Peak Oil, Economic Growth, and Wildlife 
Conservation (pp. 63-82). New York, NY: Springer New York.

Roger, P.-A., \& Watanabe, I. (1984). Algae and aquatic weeds as source of organic matter and plant nutrients for wetland rice. Organic matter and rice, 147-168.

Schlesinger, W. H., \& Bernhardt, E. S. (2013). Biogeochemistry: an analysis of global change: Academic press.

Strik, D. P. (2008a). Green electricity production with living plants and bacteria in a fuel cell. International Journal of Energy Research, 32(9), 870-876. doi:10.1002/ er.1397

Strik, D. P. (2008b). Renewable sustainable biocatalyzed electricity production in a photosynthetic algal microbial fuel cell (PAMFC). Applied Microbiology and Biotechnology, 81(4), 659-668. doi:10.1007/s00253-008-1679-8

Strik, D. P., Timmers, R. A., Helder, M., Steinbusch, K. J., Hamelers, H. V., \& Buisman, C. J. (2011). Microbial solar cells: applying photosynthetic and electrochemically active organisms. Trends in biotechnology, 29(1), 41-49.
Sudirjo, E. (2020). Plant microbial fuel cell in paddy field: A power source for rural area. Wageningen University.

Taiz, L., \& Zeiger, E. (2006). Plant Physiology Sinauer Associates. Inc., Sunderland, MA.

Wang, C., \& Guo, L. (2012). Systematic comparison of C3 and C4 plants based on metabolic network analysis. Paper presented at the BMC systems biology.

Wetser, K. (2016). PhD Dissertation. Electricity from wetlands: Technology assessment of the tubular Plant Microbial Fuel Cell with an integrated biocathode. Wageningen.

Wetser, K. (2017). Electricity from wetlands: Tubular plant microbial fuels with silicone gas-diffusion biocathodes. Applied Energy, 185, Part 1, 642-649. doi:http://doi.org/10.1016/ j.apenergy.2016.10.122

Wetser, K., \& Liu, J. (2015). Plant microbial fuel cell applied in wetlands: Spatial, temporal and potential electricity generation of Spartina anglica salt marshes and Phragmites australis peat soils. Biomass and Bioenergy, 83, 543-550. doi:http:// $\mathrm{d} x . \mathrm{d} o \mathrm{i} .0 \mathrm{rg} / 10.1016 /$ j.biombioe.2015.11.006 